\title{
Effect of Iron on Erythropoietin Production in Anaemic Piglets
}

\author{
By Ø. V. Sjaastad ${ }^{\prime}$, T. Framstad ${ }^{2}$ and A. K. Blom Blo $^{l}$
}

'Department of Biochemistry, Physiology and Nutrition, and ${ }^{2}$ Department of Reproduction and Forensic Medicine, Norwegian College of Veterinary Medicine, Oslo, Norway.

\begin{abstract}
Sjaastad, Ø.V., T. Framstad and A. K. Blom: Effect of iron on erythropoietin production in anaemic piglets. Acta vet. med. 1996, 37, 133-138. - In the present study the response of plasma erythropoietin to iron injection in anaemic piglets was examined. At the age of 16 days, 4 piglets from the same litter were given $180 \mathrm{mg}$ iron subcutaneously. After iron injection, blood samples for estimation of erythropoietin activity in plasma, haemoglobin concentration, and reticulocyte counts were taken every 6 or $12 \mathrm{~h}$ for $31 / 2$ days. Plasma erythropoietin activity was estimated by a monoclonal enzyme-immunoassay (ELISA), developed for human erythropoietin. On the day of iron injection, haemoglobin concentration ranged between 41 and $48 \mathrm{~g} / 1$, reticulocyte counts from 9 to 17 percent, and plasma erythropoietin between 22 and $144 \mathrm{mU} / \mathrm{ml}$. In 3 of the 4 piglets, iron injection resulted in a 2-6 fold increase in erythropoietin activity. Maximal erythropoietin activities were observed 24-42 h after injection, and after $66 \mathrm{~h}$, the activities were close to the pretreatment values. It is concluded that in our experiment, iron, per se, has stimulated erythropoietin production.
\end{abstract}

anaemia; ELISA; pig.

\section{Introduction}

Erythropoiesis is regulated through a feedback loop, involving erythropoietin, a hormone produced mainly in the kidney in adults (e.g Jelkman 1992). Since both anaemia and low $\mathrm{PO}_{2}$ stimulate erythropoietin production, it has been concluded that erythropoietin production is regulated by the tissue oxygen tension. An as yet unidentified intrarenal $\mathrm{PO}_{2}$-sensor is supposed to monitor the availability of $\mathrm{O}_{2}$.

In piglets, serious anaemia develops rapidly after birth, unless iron is supplemented (Steinhardt et al.1984, Holter et al.1991). In a previous experiment we found that the erythropoietin activity in 14 days old piglets who had not been supplemented with iron was about 20 times higher than the mean activity in piglets injected with iron one day after birth (Sjaastad et al. 1992). Four days after iron treatment on day 14 , the anaemia had been partly corrected and erythropoietin had dropped to very low values.

The main objective of the present study was to examine more closely the changes in erythropoietin activity and haemoglobin upon iron treatment of piglets suffering from iron-deficiency anaemia.

\section{Materials and methods}

A litter of 8 Norwegian Landrace piglets was kept in a pen together with the mother. The piglets had access to water from day one after birth and to pelleted food from day 11. Before iron administration on day 16 , blood samples were taken on days 11,14 and 16 . On day 16 , after 
blood sampling, the piglets were given $180 \mathrm{mg}$ iron, as dextranous iron, subcutaneously. Blood samples of one $\mathrm{ml}$ were taken from the jugular vein $12,18,24,36,42,48,60,66,72$ and $84 \mathrm{~h}$ after iron administration. In 4 of the piglets, plasma erythropoietin was estimated by a monoclonal enzyme-immunoassay (ELISA), using human erythropoietin antibodies (EpoElisa test, Medac, Hamburg). Since porcine erythropoietin is unavailable, the degree of crossreaction between this antigen and the antibodies used could not be tested, and thus only relative values for erythropoietin are given. The coefficient of interassay variation of the method was about 10 percent. Haemoglobin concentration was estimated by Technicon $\mathrm{H}^{*} 1$, whereas reticulocytes were counted in a Sysmex R1000.

\section{Results}

All the piglets developed serious anaemia during their first 2 weeks of life (Fig.1). Haemoglobin concentration in the 4 piglets examined varied between 41 and $48 \mathrm{~g} / \mathrm{l}$ in blood samples taken on day 16 , just prior to iron treatment. In piglets 1-3, haemoglobin did not change much from day 11 to day 16 . In the fourth piglet, there was a moderate increase in haemoglobin during the last part of this period.

The erythropoietin activity in plasma on the day of iron treatment ranged from 22 to $144 \mathrm{mU} / \mathrm{ml}$, the average being 88.5 (S.D. 58.2 ). The lowest erythropoietin activity was found in 1 of the 2 piglets with the least severe anaemia (no 3 ). In piglets $1-3$, erythropoietin activity was fairly stable the days prior to iron treatment. In piglet no 4 , erythropoietin activity increased by a factor of nearly 2 during this period.

In 3 of the 4 piglets, iron treatment resulted in a rapid and substantial increase in plasma erythropoietin, followed by an equally rapid decrease to activities lower than those found before treat- ment (Fig.1). In these piglets, the erythropoietin activity $18 \mathrm{~h}$ after iron injection exceeded the pretreatment values. The highest erythropoietin values were encountered 24-42 h after iron administration. Haemoglobin increased much slower than erythropoietin, and the haemoglobin values were still strongly subnormal at the time when erythropoietin started to decline.

In piglet no 4, erythropoietin activity fell abruptly down to nearly undetectable activities upon iron treatment.

In all the piglets, reticulocyte counts increased during the observation period. In the blood samples taken just before iron treament, the counts varied between 9 and 17 percent. The changes in reticulocyte counts after iron injection were moderate and did not exhibit any consistent pattern (Fig. 1).

\section{Discussion}

At birth, haemoglobin concentration in pigs is lower than in adults. The changes in haemoglobin concentration in the neonate period depend on whether iron is supplemented or not (Steinhardt et al. 1984, Holter et al. 1991). In modern rearing systems, piglets which are not given iron, exhibit a continuous drop in haemoglobin as long as the piglets feed only on milk from the mother, and a serious iron deficiency anaemia develops. In piglets given iron shortly after birth, however, the postpartum drop in haemoglobin lasts for only a few days (Bollwahn et al. 1971, Holter et al. 1991).

Reticulocyte counts on the day of iron treatment were in the present study as high as 9-17 percent (Fig. 1). Thus, even though the piglets were low in haemoglobin before iron treatment, erythropoiesis was very active. In all the piglets, except no 4 , haemoglobin was fairly constant during this period. Piglets, as those used in our studies, increase their weight tremendously 
Piglet no. 1

Piglet no. 2

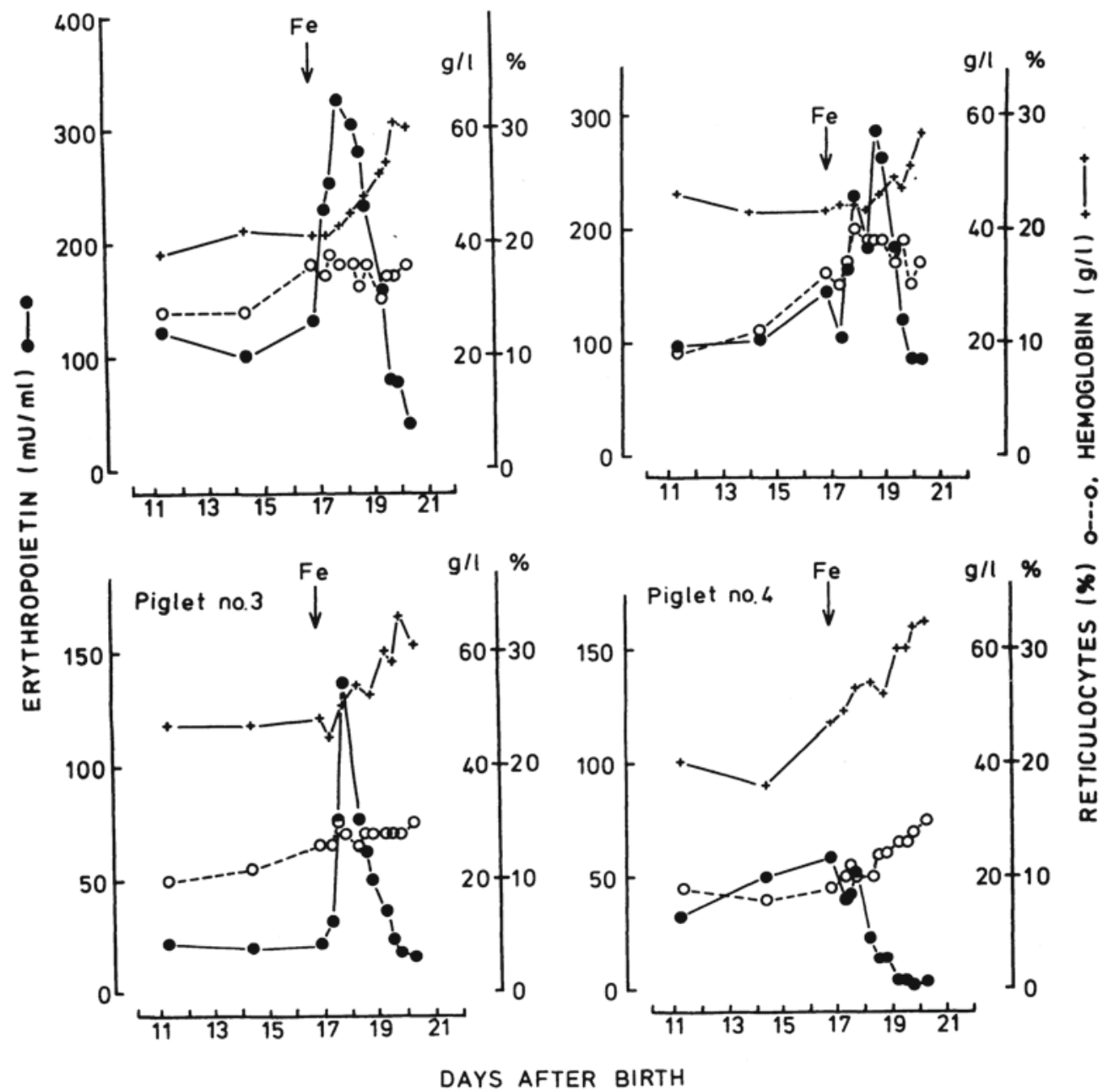

Figure 1. Erythropoietin activity in plasma before and after subcutaneous injection of $180 \mathrm{mg}$ dextraneous iron. Arrows indicate time of injection. Note that 2 different scales for erythropoietin activity are used.

fast. Reticulocyte counts indicative of a very active erythropoiesis is therefore what, a priori, should be expected. In piglets 1-3, iron was obviously ingested to an extent which caused an increase in haemoglobin mass that roughly matched the increase in body weight, the result being a fairly constant concentration of hae- moglobin. The exogenous iron mainly stemmed from pelleted food, since the milk of sows is very poor in iron.

Iron treatment caused a rapid increase in haemoglobin concentration in all the piglets, the average increase being about 40 percent during the 3.5 days posttreatment period. In piglets 1- 
3 , this increase in haemoglobin was accompanied by only minor changes in reticulocyte counts.

In a previous study, erythropoietin activities at birth were close to the detection limit of the method used (Sjaastad et al. 1992). Independent of whether iron was supplemented or not, erythropoietin activity in piglets increased largely during the first days of life, whereafter it dropped rapidly. Plasma erythropoietin in 14 days old piglets which have not received iron supplementation, were, nevertheless, much higher than the corresponding values in piglets given iron shortly after birth (Sjaastad et al. 1992). Since piglets which are not given any extra iron develop serious anaemia, such a difference in erythropoietin activity accords with the fact that hypoxia is a stimulus of erythropoietin secretion.

In 3 of the 4 two-week-old piglets examined in the present study, a large, rapid and brief increase in erythropoietin activity was observed upon iron injection. This change in erythropoietin activity can not easily be explained on the basis of the accepted feed-back relationship between tissue oxygen supply and erythropoietin production, since haemoglobin concentration was almost constant in the period prior to injection (Fig. 1). In this context it is also worth mentioning that erythropoietin activities were found to be nearly constant in the period 14-21 days after birth in untreated piglets blood sampled by a regime identical to that used in the present study (Framstad et al. unpublished). The observed increase in erythropoietin is thus most likely a more "direct" effect of iron.

The increase in erythropoietin upon iron injection is very brief (Fig. 1), and to secure its detection, blood samples have to be taken every $12 \mathrm{~h}$. Infrequent blood sampling is by all probability the reason why this increase in erythropoietin activity upon iron injection was overlooked in a previous experiment (Sjaastad et al.
1992).

The stimulatory effect of iron injections upon erythropoietin activity is not a consistent phenomenon. Whereas erythropoietin activity increased upon iron injection in piglets 1-3, it dropped in piglet no 4 (Fig. 1). The difference in response to iron injection in piglets 1-3 versus no 4 is most likely due to differences in the dynamics of erythropoiesis. Piglet no 4 had probably eaten more iron-containing pellets during the days prior to iron injection than the remaining 3 , the result being an increase in haemoglobin from day 14. This increase, although moderate, may have reduced erythropoietin production by feed-back mechanisms. It has also earlier been observed that when an anemic situation is treated, erythropoietin returns to low values long before a normalization in haemoglobin has taken place. Thus, Bjarnason et al. (1984) state that this is the case when an iron deficiency anaemia is corrected. Such a mechanism might also have contributed to the rapid drop in erythropoietin activity after the peak in piglets 1-3. As far as piglet no 4 is concerned, the possibility that the increase in erythropoietin in the period before iron injection in fact represents a response to ingested iron, can not be rejected. It is worth mentioning that a smaller, but nevertheless significant increase in erythropoietin was observed when the dose of iron was reduced from 180 to $12 \mathrm{mg}$ (Sjaastad et al. unpublished).

The mechanism behind the increase in erythropoietin activity upon iron injection in the piglets examined in the present experiment, except no 4 , is at present an enigma. The lack of increase in pig no 4 in the present study and in many piglets with normal haemoglobin in other litters (Sjaastad et al. unpublished), strongly rejects the possibility that the observed increases in the other piglets should be artefacts due to interference of dextranous iron in the erythropoietin assay. Further, in contrast to the 
sharp peaks observed in the present study, the plasma concentration of iron was maintained at a plateau in the period 6 to $36 \mathrm{~h}$ after a subcutaneoues injection of $200 \mathrm{mg}$ iron (Thorèn-Tolling 1975).

Both in humans (Cotes et al. 1989, Bechensteen et al. 1993), and dogs (Leibold et al. 1994), there were a few cases of invalid serum estimates of erythropoietin, due to presence of cross-reactant factors, when an ELISA kit method (Bechensteen et al. 1993, Leibold et al. 1994) or a RIA method (Cotes et al. 1989) was used. There is a slight possibility that variations in the concentrations of such crossreacting factors, if present, could result in curve profiles for erythropoietin similar to those observed in the present study. When the RIA method of Cotes et al. 1989 was used in studies of piglets, curve profiles similar to those in the present study were obtained (Sjaastad et al. unpublished). Although no other physiological stimulus of erythropoietin production than tissue hypoxia has been established, there are indications of a more complex regulatory system (e.g. Jelkman 1992). Sanengen \& Halvorsen (1985) found that hypertransfusion did not block erythropoietin production in anemic neonate mice. They suggested that factors related to growth per se may be involved in the control of erytropoietin production. In this context it is worth mentioning that insulin-like growth factor 1 (IGF 1) has been reported to increase erythropoietin production (Kurtz et al. 1982). The idea that other factors than hypoxia stimulate erythropoietin production is also supported by the observation that treatment with cytostatic drugs resulted in increases in erythropoietin activity before any change in haemoglobin could be detected (Birgegård et al. 1989). Further, based on experiments in which blood from rats exposed to hypoxia caused increased erythropoietin production in recipient rats, Pagel et al. (1994) postulated the existence of an extrarenal humoral factor stimulating erythropoietin production. Since the rapid changes in erythropoietin activity upon iron administration observed in the present study are not explainable on the basis of changes in the tissue oxygen tension, it is tempting to speculate that a humoral factor is involved also in the stimulatory effect of iron on erythropoietin production.

It has been shown that erythropoietin influences cellular iron metabolism by activating iron responsive factor, IRF (Weiss et al. 1994). The present study strongly indicates that a reverse relationship also exists; iron influences erythropoietin production. Injection of iron into iron deficient piglets thus seems to increase the oxygen transport capacity of the blood by two different mechanisms: 1) directly, by providing iron for haemoglobin synthesis 2) indirectly, by increasing the concentration of erythropoietin. The increase in erythropoietin caused by iron might have a functional value. Its importance should nonetheless be interpreted with caution, since it is of short duration and since growth, and thus erythropoiesis, in neonate mice ( $\mathrm{Be}$ chensteen \& Halvorsen 1994) and pigs (Sjaastad et al. 1992) is rapid also in periods with a low plasma concentration of erythropoietin. Further, it should be kept in mind that the concentration in peripheral plasma gives limited information of the dynamics in the function of any hormone.

\section{References}

Bechensteen AG, Halvorsen S: Serum immunoreactive erythropoietin (SIEPO) during the early anemia in mice. Effects of parenteral iron. Clin. Investig. 1994, 72, B17.

Bechensteen AG, Lappin TRJ, Marsden J, Muggleston D, Cotes PM: Unreliability in immunoassays of erythropoietin: anamalous estimates with an assay kit. Br. J. Haematol. 1993, 83, 663-664.

Birgegård G, Wide L, Simonsson B: Marked erythropoietin increase before fall in $\mathrm{Hb}$ after treatment with cytostatic drugs suggests mechanism other 
than anaemia for stimulation. Br. J. Haematol. 1989, 72, $462-466$.

Bjarnason I, Cotes PM, Knowles S, Reid C, Wilkens $R$, Peters. TJ: Giant lymph node hyperplasia (Castleman's disease) of the mesentery. Observations on the associated anaemia. Gastroenterology, 1984, 87, 216-223.

Bollwahn $W$, Vaske $T$, Rojas $M$, Wenz I: Die Hämatopoese neugeborener Ferkel und ihre Beeinflussung durch Eisendextran ( $\left.{ }^{8} \mathrm{Myofer}\right)$ (Haematopoiesis in newborn pigs, and the effect of iron dextran ( ${ }^{\circledR}$ Myofer). Das Blaue Hefte, 1971, 45, 171-182.

Cotes PM, Tam RC, Reed P, Hellebostad M: An immunological cross-reactant of erythropoietin in serum which may invalidate EPO radioimmunoassay. Br. J. Haematol. 1989, 73, 265-268.

Holter PH, Framstad T, Aulie A, Refsum HE, Sjaastad $\emptyset \mathrm{V}$ : Effect of iron treatment on erythrocyte parameters in postnatal anaemia in the pig. Pediatr. Hematol. Oncol. 1991, 8, 1-11.

Jelkman W: Erythropoietin: structure, control of production and function. Physiol. Rev. 1992, 72, 449-489.

Kurtz A, Jelkman W, Bauer C: A new candidate for the regulation of erythropoiesis. FEBS letters, 1982, 149, 105-108.

Leibold W, Bornmann-Hollstein A, Schuberth HJ: Erythropoietin (epo) in dogs and cats: diagnostic and therapy. ESVIM Newsletter, 1994, 4, 10-11.

Sanengen T, Halvorsen $S$ : Regulation of erythropoiesis during rapid growth. Br. J. Haematol. 1985, 61, 273-279.

Pagel H, Frackowski U, Weiss Ch: Transfusion of blood from exhypoxic rats augments the production of erythropoietin (EPO) in recipients. Clin. Investig. 1994, 72, B 5.

Sjaastad ØV, Framstad T, Blom AK: Neonatal changes in plasma erythropoietin in fast growing pigs. Acta vet. scand.1992, 33, 249-252.
Steinhardt $M$, Bünger $U$, Furcht $G$ : Zum Eisenbedarf des Schweines in den ersten 2 Lebensmonaten (Iron requirements in pigs during their first 2 months of living). Arch. Exp. Veterinärmed. 1984, 38, 497-515.

Thorén-Tolling $K$ : Studies on the absorption of iron after oral administration in piglets. Acta vet. scand. 1975, 54 (Suppl.), 1-121.

Weiss $G$, Urbanek $M$, Fuchs $D$, Wachter $H$, Grünewald $K$ : Erythropoietin influences intracellular iron regulation via iron responsive elements. Clin. Investig. 1994, 72, B 9.

\section{Sammendrag \\ Virkning av jern på erytropoietinproduksjon.}

Artikkelen omhandler virkningen av jern på plasmakonsentrasjonen av erytropoietin hos anemiske grisunger.

Fire 16 dager gamle grisunger fra samme kull ble gitt $180 \mathrm{mg}$ jern subkutant. Etter jerninjeksjonen ble blodprøver tatt hver 6 . eller 12 . time i $3 \frac{1}{2}$ døgn for bestemmelse av erytropoietinaktivitet i plasma, hemoglobin og reticulocyttantall. Plasma erytropoietin ble bestemt med en monoklonal enzym-immunoassay (ELISA) metode utviklet for bestemmelse av humant erytropoietin. På dag 16, forut for jerninjeksjonen, varierte hemoglobin mellom 41 og $48 \mathrm{~g} / \mathrm{l}$, reticulocyttantallet mellom 9 og 17 prosent, og erytropoietinaktiviteten mellom 22 og $144 \mathrm{mU} / \mathrm{ml}$. Hos 3 av de 4 grisungene, resulterte jerninjeksjon i en 2-6 fold øning i erytropoietinaktiviteten. Erytropoietinaktiviten nådde maksimum 24-42 timer etter injeksjonen, og etter 66 timer var aktiviteten tilbake til utgangsnivået. Vi konkluderer med at i våre eksperimenter har jern, per se, stimulert erytropoietinproduksjonen.

(Received July 10, 1995; accepted January 8, 1996).

Reprints may be obtained from: $\varnothing$. V. Sjaastad, Department of Biochemistry, Physiology and Nutrition, Norwegian College of Veterinary Medicine, P.O. Box 8146, Dep., N-0033 Oslo, Norway, Fax number 46-22600985. 